\title{
J!III
}

\section{ANALISIS LIKUIDITAS DAN PROFITABILITAS PADA PT BPR PARO LABA TONDANO}

\author{
Trotjevina Rorimpandey¹, Meidy S. Kantohe², Aprili Bacilius ${ }^{3}$
}

\author{
Akuntansi, FE Universitas Negeri Manado, Tondano¹, FE Universitas Negeri Manado, Tondano², FE Universitas \\ Negeri Manado, Tondano ${ }^{3}$ \\ e-mail : vrorimpandei@gmail.com¹, meidysskantohe@unima.ac.id², aprilibacilius@unima.ac.id ${ }^{3}$
} Diterima : 05-05-2021 Disetujui : 21-05-2021

\begin{abstract}
ABSTRAK
Tujuan penelitian ini adalah untuk mengetahui bagaimana rasio likuiditas dan rasio profitabilitas PT. Bank Perkreditan Rakyat Paro Laba. Metode penelitian yang digunakan adalah metode analisis deskriptif kuantitatif dengan teknik pengumpulan data yang digunakan adalah observasi dan dokumentasi yang diperoleh dari laporan publikasi otoritas jasa keuangan atas laporan keuangan Bank Perkreditan Rakyat (BPR) Paro Laba periode 2015-2019. Hasil penelitian pada bank perkreditan rakyat paro laba menunjukkan bahwa rasio likuiditas yang diukur dari Cash Ratio menunjukkan bahwa bank mampu memenuhi hutang jangka pendek, Quick Ratio menunjukkan bank belum mampu memenuhi kewajiban kepada para deposan dengan harta yang paling likuid. Kemudian untuk loan to deposit ratio menunjukkan bank tidak mampu melunasi kembali kewajiban kepada nasabah menggunakan kredit yang diberikan bank dengan dana yang diterima bank. Sedangkan untuk rasio profitabilitas diukur dari Net Profit Margin menunjukkan bank belum mampu dalam menghasilkan laba bersih dari kegiatan operasinya, Return On Assets menunjukkan bank mampu menghasillkan laba bersih sebelum pajak dari jumlah aktiva yang dimiliki dan Return On Equity menunjukkan bank mampu dalam mendapatkan keuntungan dari modal sendiri.
\end{abstract}

\section{Kata kunci : Laporan keuangan, Likuiditas, Profitabilitas}

\begin{abstract}
The purpose of this study was to determine how the liquidity ratio and profitability ratio of PT. Bank Perkreditan Rakyat Paro Laba. The research method used is a quantitative descriptive analysis method with the data collection technique used is observation and documentation obtained from the publication reports of the financial services authority on the financial statements of Bank Perkreditan Rakyat (BPR) for the 20152019 period. The results of the research on Bank perkreditan rakyat Paro laba show that the liquidity ratio as measured by the Cash Ratio shows that the bank is able to meet short-term debt, the Quick Ratio shows that the bank has not been able to fulfill its obligations to depositors with the most liquid assets. Then the loan to deposit ratio shows that the bank is unable to repay its obligations to customers using the credit provided by the bank with the funds received by the bank. As for the profit ratio
\end{abstract}

Keywords : Financial statements, Liquidity, Profitability 


\section{Jing}

\section{PENDAHULUAN}

Di era globalisasi saat ini pertumbuhan ekonomi yang semakin pesat banyak perusahaan bertumbuh dan berkembang. Tujuan didirikannya suatu perusahaan adalah untuk memperoleh laba/keuntungan dan mempertahankan kelangsungan perusahaan tersebut. Termasuk didalamnya lembaga keuangan yaitu perbankan. Perbankan merupakan suatu hal yang menyangkut tentang bank, mencakup kelembagaan, kegiatan usaha, serta cara dan proses dalam melakukan kegiatan usahanya (Handayani, M., \& Marlius, n.d.). Perbankan merupakan lembaga keuangan yang sangat berperan penting dalam bidang perekonomian suatu negara termasuk di Indonesia (Fitri \& Marlius, 2019).

Dengan adanya perbankan perkembangan perekonomian meningkat dalam menunjang taraf hidup rakyat. Menurut undang-undang RI No.10 Tahun 1998 Bank merupakan badan usaha yang kegiatannya menghimpun dana dari masyarakat dalam bentuk simpanan seperti tabungan, deposito, giro dan menyalurkannya kepada masyarakat dalam bentuk kredit dan bentuk-bentuk lainnya dengan tujuan meningkatkan taraf hidup orang banyak. Jenis perbankan terdiri dari: (a). Bank Umum (b). Bank Perkreditan Rakyat (BPR). Bank umum adalah bank yang melaksanakan kegiatan usaha secara konvensional dan atau berdasarkan prinsip syariah yang dalam kegiatannya memberikan jasa dalam lalu lintas pembayaran. Bank Perkreditan Rakyat (BPR) adalah bank yang tidak memberikan jasa dalam lalu lintas pembayaran, yang dalam pelaksanaan kegiatanusahanya dapat secara konvesional atau berdasarkan prinsip syariah. Bank Perkreditan Rakyat menerima simpanan hanya dalam bentuk deposito berjangka, tabungan, dan/atau bentuk lainnya yang dipersamakan dengan itu(Nur, D Eva dan Elim, 2015). Dengan adanya Kepercayaan masyarakat terhadap perbankan terus meningkat ditandai dengan bertambahnya produk dan jasa yang ditawarkan kepada masyarakat, oleh karena itu persaingan di dunia perbankan semakin ketat sehingga bank harus memberikan kualitas terbaik untuk memberikan kepuasan kepada masyarakat.

Sejalan dengan kemajuan perekonomian yang semakin pesat dengan adanya lembaga keuangan, menuntut perusahaan untuk dapat mempertahankan kelangsungan hidup perusahaan, untuk dapat mempertahankan perusahaan perlu adanya kinerja yang baik dari perusahaan tersebut. Untuk memutuskan bahwa perusahaan memiliki kinerja yang baik maka harus dinilai dari laporan keuangan suatu perusahaan. Oleh karena itu penyajian laporan keuangan lengkap dan benar, wajib untuk memperlihatkan kinerja keuangan setiap periode. (Munawir, 2014) "laporan keuangan pada dasarnya adalah hasil dari proses akuntansi yang dapat digunakan sebagai alat untuk berkomunikasi antara data keuangan atau aktivitas suatu perusahaan dengan pihak-pihak yang berkepentingan dengan data atau aktivitas perusahaan tersebut". Laporan keuangan yang dikenal adalah Neraca, Laporan Laba Rugi, Laporan Perubahan Ekuitas, Laporan Arus Kas, serta Laporan Posisi Keuangan (Ottay, M. C., \& Alexander, 2015). Laporan keuangan diperlukan untuk mengevaluasi kinerja yang dicapai manajemen perusahaan di masa lalu, dan sebagai bahan penilaian dalam membuat rencana perusahaan ke depan dengan menggunakan analisis rasio.

Analisis rasio merupakan alat yang penting dalam menganalisis keuangan(Rabuisa, 2018). Analisa laporan keuangan pada dasarnya adalah perhitungan rasio-rasio untuk memperlihatkan kondisi keuangan di waktu lalu, saat ini, dan kemungkinan di masa depan. Analisis Rasio adalah suatu teknis untuk menganalisis laporan keuangan dari suatu badan usaha dengan menggunakan ukuran atau rasio tertentu, yang bertujuan untuk mengetahui hubungan dari pos -pos yang ada dalam neraca atau laporan rugi laba itu secara individual atau kombinasi dari kedua laporan tersebut (Herdyanto, 2012). Rasio keuangan menunjukkan perubahan yang terjadi di dalam perusahaan serta kemampuan perusahaan mengelola kekayaan perusahaan dalam meningkatkan nilai dari perusahaan. Rasio menggambarkan suatu hubungan atau perbandingan antara suatu jumlah tertentu dengan jumlah yang lain, dan dengan menggunakan alat analisa berupa rasio ini akan dapat menjelaskan atau memberi gambaran kepada penganalisa tentang baik buruknya keadaan keuangan suatu perusahaan.(Pangemanan, W. I,2017)

Pada dasarnya ada beberapa rasio yang biasa digunakan yaitu rasio likuiditas, rasio aktivitas, rasio profitabilitas dan rasio solvabilitas. Dalam penelitian ini menggunakan analisis rasio likuiditas serta rasio profitabilitas. Rasio likuiditas adalah rasio yang menggambarkan 
JAIM: Jurnal Akuntansi Manado, Vol. 2 No. 3 Desember 2021

e-ISSN 2774-6976

kemampuan bank untuk menyelesaikan kewajiban jangka pendeknya (Rahmayeli, D. S., \& Marlius, 2017). Likuiditas adalah kemampuan bank memenuhi penarikan dana oleh para nasabah, deposan, kewajiban jatuh tempo dan memenuhi permintaan kredit tanpa penundaan (Anggraeni, R. K., 2014). Likuiditas merupakan rasio yang mengukur kemampuan perusahaan dalam memenuhi kewajiban jangka pendeknya, rasio yang dipakai dalam analisis rasio likuiditas ialah, Cash Ratio, Quick Ratio serta Loan to Deposit Ratio. Sedangkan rasio profitabilitas alat untuk mengukur kemampuan bank dalam menghasilkan laba (Kasmir, 2014). Rasio profitabilitas yang digunakan adalah, Net Profit Margin (NPM), Return on Equity (ROE) dan Return on Asset (ROA).

PT. Bank Perkreditan Rakyat (BPR) merupakan bank yang melakukan kegiatan usahanya dengan cara konvensional atau berdasarkan pada prinsip syariah, yang dalam kegiatannya tidak memberikan pelayanan dalam lalu lintas pembayaran.

Tabel 1

Data Keuangan PT BPR Paro Laba Tondano

Tahun 2015 - 2019

(Ribuan Rp)

\begin{tabular}{lrrrrr}
\hline \multicolumn{1}{c}{ Keterangan } & \multicolumn{1}{c}{2015} & \multicolumn{1}{c}{2016} & \multicolumn{1}{c}{2017} & \multicolumn{1}{c}{2018} & \multicolumn{1}{c}{2019} \\
\hline Kas & 753.793 & 671.819 & 717.176 & 382.388 & 267.067 \\
Total Aset & 18.839 .056 & 21.231 .567 & 22.582 .273 & 25.363 .380 & 28.041 .343 \\
Hutang Lancar & 14.380 .079 & 11.372 .460 & 12.286 .401 & 14.041 .781 & 16.225 .116 \\
Modal & 1.500 .000 & 6.000 .000 & 6.000 .000 & 6.000 .000 & 6.000 .000 \\
Laba sebelum Pajak & 2.657 .306 & 3.477 .000 & 3.256 .419 & 4.114 .055 & 5.004 .959 \\
Laba Bersih & 2.174 .326 & 2.826 .031 & 2.612 .755 & 3.298 .398 & 3.970 .910 \\
Pendapatan Operasional & 7.186 .243 & 8.328 .447 & 9.433 .117 & 10.471 .007 & 13.231 .845 \\
\hline
\end{tabular}

Sumber : Laporan Keuangan PT. BPR Paro Laba Tondano

Dari Data tersebut terlihat bahwa PT. BPR Paro Laba Tondano pada tahun 2015 sampai 2019, dari data laporan keuangan di atas menunjukkan jumlah kas mengalami kenaikan pada tahun 2015 dan 2017 dan terjadi penurunan di tahun 2016, 2018 dan 2019, total aset mengalami peningkatan dari tahun 2015-2019 yang cukup signifikan, hutang lancar mengalami kenaikan di tahun 2015, 2017, 2018, 2019 dan terjadi penurunan di tahun 2016, modal mengalami kenaikan dari tahun 2015- 2019, laba sebelum pajak mengalami kenaikan di tahun 2015, 2016, 2018, 2019 namun pada tahun 2017 mengalami penurunan, laba bersih mengalqmi kenaikan di tahun 2015, 2016, 2018, 2017 serta mengalami penurunan di tahun 2017, dan pendapatan operasional mengalami peningkatan dari tahun 2015-2019.

Berdasarkan penjelasan diatas, sehingga tujuan penelitian ini adalah untuk mengetahui bagaimana tingkat rasio likuiditas yang diukur dari cash ratio, quick ratio, loan to deposit ratio dan tingkat rasio profitabilitas yang diukur dari net profit margin, return on assets, Return on Equity pada PT. Bank Perkreditan Rakyat Paro Laba Tondano dalam periode 2015-2019

\section{METODE}

Penelitian ini menggunakan pendekatan deskriptif kuantitatif. Metode kuantitatif adalah penelitian dengan memperoleh data yang berupa angka-angka dan analisis menggunakan statistik. Sumber data yang digunakan dalam penelitian ini yaitu data sekunder yang berupa data laporan keuangan BPR Paro Laba Tondano. Dalam penelitian ini pengumpulan data dilakukan dengan metode observasi dan dokumentasi. metode observasi mengumpulkan data secara langsung berupa informasi tentang gambaran umum Pt. BPR Paro Laba Tondano. Metode dokumentasi menghimpun data lewat dokumen-dokumen yang ada di perusahaan dan data diperoleh dari situs resmi Otoritas Jasa Keuangan (OJK) : http://www.ojk.go.id/. Teknik analisis data yang digunakan dalam penelitian ini adalah analisis yang didasarkan pada perhitungan angka-angka untuk mengetahui tingkat likuiditas dan profitabilitas yang digunakansebagai dasar pengambilan keputusan. Data berupa laporan keuangan yang dianalisis dengan menggunakan rasio-rasio keuangan yang diperlukan untuk dapat memperoleh informasi mengenai 

profitabilitas dan likuiditas.

\section{HASIL DAN PEMBAHASAN}

Perhitungan rasio profitabilitas dan likuiditas pada PT. Bank Perkreditan Rakyat (BPR) Paro Laba Tondano Tahun 2015-2019

\section{Rasio Likuiditas}

1. Cash Ratio

Ratio ini menunjukkan kemampuan bank untuk melunasi kembali simpanan nasabah dengan alat-alat yang paling likuid yang dimiliki bank tersebut(Abolladaka, 2015). Cash Ratio yaitu rasio alat likuid terhadap dana pihak ketiga yang dihimpun bank dan harus dibayar. Rasio ini digunakan untuk menilai kemampuan bank melunasi kembali simpanan nasabah (deposan) saat ditarik menggunakan alat likuid yang dimilikinya.(Badria, Medianana dan Marlius, 2018). Penggolongan nilai predikat kesehatan Dalam Surat Edaran Bank Indonesia No. 6/23/DPNP/2004, Cash Ratio sebagai berikut: Sehat: $>4,05 \%$ ke atas, Cukup sehat : $>3,30 \%-<4,05 \%$, Kurang sehat : $>2,55 \%-<3,30 \%$, Tidak sehat : $<2,55 \%$

Tabel 2

Perhitungan Cash Ratio BPR Paro Laba

Tahun 2015 - 2019

(Ribuan Rp)

\begin{tabular}{|c|c|c|c|c|c|c|}
\hline & Komponen & 2015 & 2016 & 2017 & 2018 & 2019 \\
\hline \multicolumn{7}{|c|}{ a. Aset Likuid } \\
\hline - & Kas & 753.793 & 671.819 & 717.176 & 382.388 & 267.067 \\
\hline & Surat Berharga & 0 & 0 & 0 & 0 & 0 \\
\hline & $\begin{array}{l}\text { Penempatan pada } \\
\text { bank lain }\end{array}$ & 1.605 .344 & 2.089 .706 & 2.926 .791 & 3.063 .190 & 4.547 .098 \\
\hline Jumla & & 2.359.137 & 2.761 .525 & 3.643.967 & 3.445 .578 & 4.814.165 \\
\hline \multicolumn{4}{|c|}{ b. Hutang Jangka } & \multicolumn{2}{|c|}{ Pendek } & \\
\hline$-K$ & wajiban Segera & 33.932 & 39.030 & 28.292 & 31.820 & 100.891 \\
\hline $\mathrm{T}$ & bungan & 5.640 .147 & 6.520 .430 & 7.155 .609 & 8.617 .461 & 7.620 .725 \\
\hline $\mathrm{D}$ & posito & 8.706 .000 & 4.813 .000 & 5.102 .500 & 5.338 .500 & 8.503 .500 \\
\hline Jumla & & 14.380 .079 & 11.372 .460 & 12.286 .401 & 14.041 .781 & 16.225 .116 \\
\hline
\end{tabular}

Sumber : Data Olahan

Rumus :

$$
\text { Cash Ratio }=\frac{\text { liquid Assets }}{\text { S5ort term borro: } \mathrm{in}<} \times 100 \%
$$


JAIM: Jurnal Akuntansi Manado, Vol. 2 No. 3 Desember 2021

Cash Ratio $=\frac{\text { A.CDE.FC'G }}{\text { FH.CIJ.JGE }} \times 100 \%=16,40 \%$

e-ISSN 2774-6976

Artinya : Bank mampu memenuhi kewajibannya dengan alat likuid yang dimiliki oleh bank Tahun 2015 ini berarti bank dapat dikatakan sehat karena Cash Ratio pada BPR Paro Laba sebesar 16,40\%, Dalam perhitungan tahun 2016 bank mampu memenuhi kewajibannya dengan alat likuid yang dimilikinya dengan Cash Ratio sebesar 24,28\%, perhitungan tahun 2017 bank mampu kembali memenuhi kewajibannya dengan alat likuid yang dimiliki, dengan Cash Ratio sebesar 29,65\% bank tersebut dapat dikatakan sehat, Pada tahun 2018 bank mampu memenuhi kewajibannya dengan alat likuid yang dimiliki oleh bank dengan Cash Ratio pada BPR Paro Laba sebesar 24,53\% bank dapat dikatakan sehat, tahun 2019 bank mampu kembali memenuhi kewajiban dengan alat likuid yang dimiliki oleh bank dengan Cash Ratio sebesar 29,67\% bank dapat dikatakan sehat.

2. Quick ratio

Quick ratio merupakan rasio yang menunjukkan kemampuan aktiva lancar bank yang paling likuid mampu menutupi hutang lancarnya(Faizal Cholid, 2014). Rasio ini digunakan untuk mengukur kemampuan bank dalam memenuhi kewajiban terhadap para deposan (pemilik simpanan giro, tabungan dan deposito) dengan harta yang paling likuid yang dimiliki oleh bank. Penggolongan nilai predikat kesehatan Quick Ratio berdasarkan Direksi Bank Indonesia Nomor 6/23/DNDP Tahun 2004 adalah : sangat sehat: $<=10 \%$, sehat : $10 \%<=$ 15\% Cukup sehat : $15 \%<=25 \%$, Kurang sehat : $10 \%<50 \%$, Tidak sehat : $<50 \%$

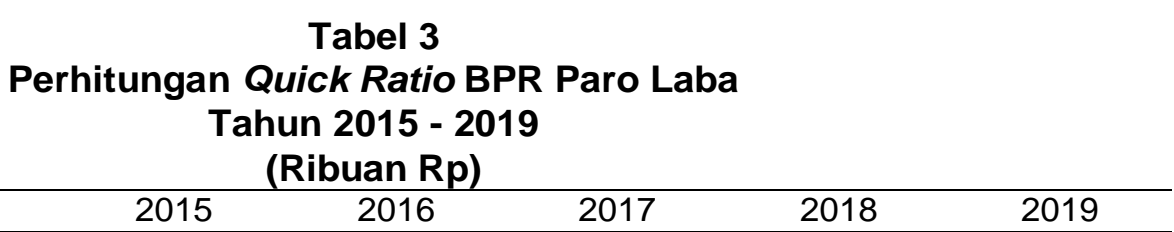

\begin{tabular}{lrrrrr}
\hline \multicolumn{1}{c}{ Komponen } & \multicolumn{1}{c}{2015} & \multicolumn{1}{c}{2016} & \multicolumn{1}{c}{2017} & \multicolumn{1}{c}{2018} & \multicolumn{1}{c}{2019} \\
\hline a. Cash Assets & & & & & \\
$\quad$ - Kas & 753.793 & 671.819 & 717.176 & 382.388 & 267.067 \\
$\quad$ - Penempatan pada & 1.605 .344 & 2.089 .706 & 2.926 .791 & 3.063 .190 & 4.547 .098 \\
$\quad$ bank lain & & & & & \\
$\begin{array}{l}\text { Jumlah } \\
\text { b. Total Deposit }\end{array}$ & $\mathbf{2 . 3 5 9 . 1 3 7}$ & $\mathbf{2 . 7 6 1 . 5 2 5}$ & $\mathbf{3 . 6 4 3 . 9 6 7}$ & $\mathbf{3 . 4 4 5 . 5 7 8}$ & $\mathbf{4 . 8 1 4 . 1 6 5}$ \\
$\begin{array}{l}\text { Simpanan } \\
\quad \text { Tabungan }\end{array}$ & & & & & \\
$\quad$ - Deposito & 5.640 .147 & 6.520 .430 & 7.155 .609 & 8.671 .461 & 7.620 .725 \\
$\quad$ Simpanan dari & 8.706 .000 & 4.813 .000 & 5.102 .500 & 5.338 .500 & 8.503 .500 \\
$\quad$ Bank Lain & & & & & \\
& & & 500.000 & 500.000 & \\
Jumlah & $\mathbf{1 4 . 3 4 6 . 1 4 7}$ & $\mathbf{1 1 , 3 3 3 , 4 3 0}$ & $\mathbf{1 2 , 7 5 8 , 1 0 9}$ & $\mathbf{1 4 , 5 0 9 , 9 6 1}$ & $\mathbf{1 6 . 1 2 4 . 2 2 5}$ \\
\hline
\end{tabular}

Sumber : Data Olahan

Rumus: Quick Ratio $=\frac{\text { cas5 assets }}{2100 \%}$

$$
\begin{aligned}
& Q R=\frac{\text { A.CDE.FCG }}{\text { FH.CHT.FHG }} \times 100 \% \text { Total Deposit } \\
& \quad=16,44 \%
\end{aligned}
$$


Artinya kemampuan BPR Paro Laba dalam penuhi kewajibannya kepada para deposan dengan harta yang sangat besar, ini bisa diamati dari hasil QR $16,44 \%$, dengan analisis bahwa Rp.1,00 deposito dapat dijamin oleh 0,1644 alat likuid yang dimiliki bank dan bank dapat dikatakan cukup sehat. QR pada tahun 2016 dilihat dari hasil QR $24,36 \%$ dengan analisis bahwa Rp.1,00 deposito dapat dijamin oleh 0,2436 alat likuid yang dimiliki bank dan bank dapat dikatakan cukup sehat. Pada tahun 2017 dari hasil QR 28,56\% dengan analisis bahwa Rp.1,00 deposito dapat dijamin oleh 0,2856 alat likuid yang dimiliki bank dan bank dapat dikatakan kurang sehat. Pada tahun 2018 dilihat dari hasil QR 23,34\% dengan analisis bahwa Rp.1,00 deposito dapat dijamin oleh 0,2334 alat likuid yang dimiliki bank dan bank dapat dikatakan cukup sehat, pada tahun 2019 dari hasil QR 29,85\% dengan analisis bahwa Rp.1,00 deposito dapat dijamin oleh 0,2985 alat likuid yang dimiliki bank dan bank dapat dikatakan kurang sehat.

3. Loan to Deposit Ratio (LDR)

Loan to Deposit Ratio adalah rasio untuk mengetahui kemampuan bank dalam membayar kembali kewajiban kepada nasabah yang telah menanamkan dananya dengan kredit-kredit yang telah diberikan kepada para debiturnya(Zebua Yuniman, 2014). Penggolongan nilai predikat kesehatan LDR berdasarkan surat edaran Direksi Bank Indonesia Nomor 6/23/DNDP Tahun 2004 adalah : sangat sehat: LDR $<=75 \%$, sehat : $75 \%<$ LDR $<=85 \%$ Cukup sehat : $85 \%$ $<$ LDR $<=100 \%$, Kurang sehat : $100 \%<$ LDR $<=120 \%$, Tidak sehat : $>120 \%$

Tabel 4

Perhitungan LDR BPR Paro Laba

Tahun 2015 - 2019

(Ribuan Rp)

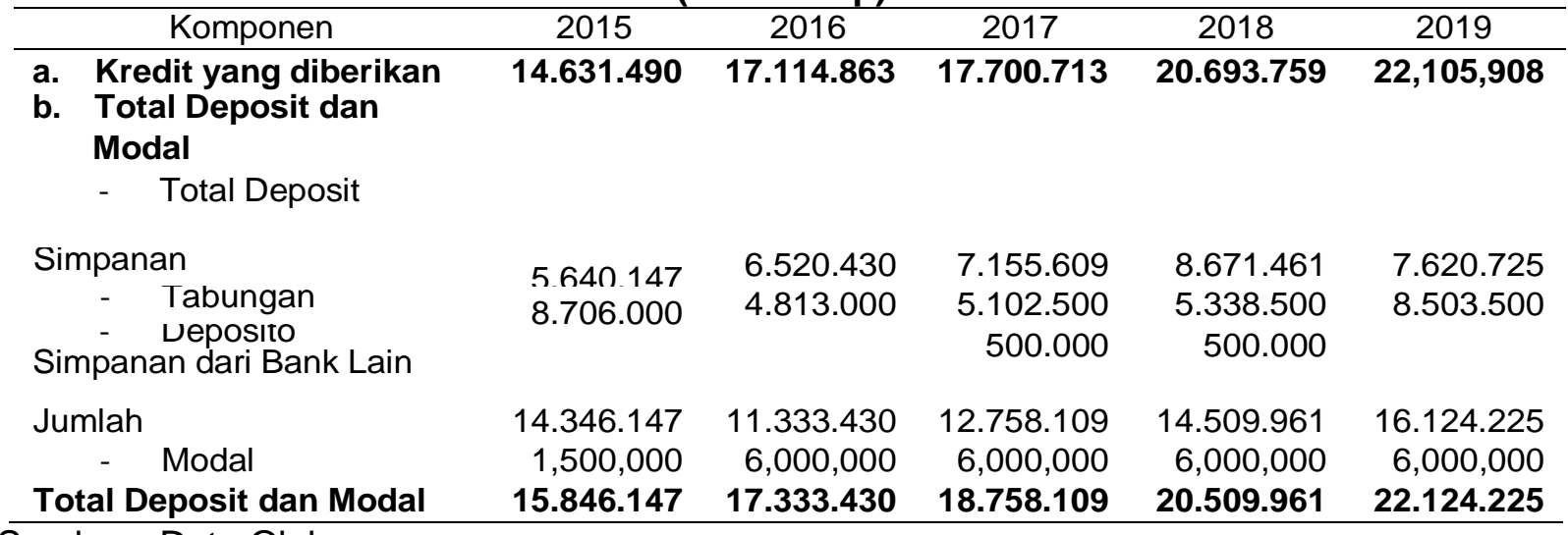

Sumber : Data Olahan

Rumus:

$L D R=\frac{\text { total Loans }}{\text { total Deposit[equity capital }} \times 100 \%$ 
$L D R=\frac{14.631 .490}{15.846 .147} \times 100 \%=92,33 \%$

Artinya, bank mampu dalam membayar kembali penarikan dana yang dilakukan oleh nasabah dengan menggunakan kredit yang diberikan bank dengan dana yang diterima oleg bank sebesar 92,33\%. Hal ini menunjukkan bahwa tahun 2015 bank dikatakan cukup sehat karena berada pada batasan $>85 \%$ yang telah ditetapkan oleh BI. Pada tahun 2016 LDR BPR Paro Laba sebesar 98,73\% hal ini menunjukkan LDR dalam posisi cukup sehat, pada tahun 2017 LDR BPR Paro Laba sebesar $94,36 \%$ hal ini menunjukkan LDR dalam posisi cukup sehat, pada tahun 2018 sebesar $100 \%$ hal ini menunjukkan LDR dalam posisi cukup sehat Pada tahun 2019 LDR sebesar 99,91\% hal ini menunjukkan LDR dalam posisi cukup sehat.

\section{Rasio Profitabilitas (profitability ratio)}

1. Net Profit margin (NPM)

Ratio adalah rasio yang menggambarkan tingkat keuntungan (laba) yang diperoleh bank dibandingkan dengan pendapatan yang diterima dari kegiatan operasionalnya (Palar, D. S., n.d.). Penetapan Peringkat Komponen NPM berdasarkan surat edaran Bank Indonesia Nomor 6/23/DNDP Tahun 2004 adalah : sangat sehat: NPM>=100\%, sehat : $81 \%<=N P M<100 \%$ Cukup sehat : $66 \%<=N P M<81 \%$, Kurang sehat : $51 \%<=N P M<66 \%$, Tidak sehat : NPM $<51 \%$

Tabel 5

Perhitungan Net Profit Margin (NPM) BPR Paro Laba

Tahun 2015 - 2019

(Ribuan Rp)

\begin{tabular}{lrrrrr}
\hline \multicolumn{1}{c}{ Komponen } & \multicolumn{1}{c}{2015} & \multicolumn{1}{c}{2016} & \multicolumn{1}{c}{2017} & \multicolumn{1}{c}{2018} & \multicolumn{1}{c}{2019} \\
\hline a. Laba Bersih & $\mathbf{2 . 1 7 4 . 3 2 6}$ & $\mathbf{2 . 8 2 6 . 0 3 1}$ & $\mathbf{2 . 6 1 2 . 7 5 5}$ & $\mathbf{3 . 2 9 8 . 3 9 8}$ & $\mathbf{3 . 9 7 0 . 9 1 0}$ \\
b. Pendapatan Operasional & & & & & \\
$\quad$ Pendapatan Bunga & 6.855 .521 & 7.849 .229 & 7.974 .707 & 9.369 .498 & 11.865 .452 \\
$\quad$ Pendapatan lainnya & 330.722 & 479.219 & 1.458 .410 & 1.101 .509 & 1.366 .393 \\
Total pendapatan Operasional & $\mathbf{7 . 1 8 6 . 2 4 3}$ & $\mathbf{8 . 3 2 8 . 4 4 7}$ & $\mathbf{9 . 4 3 3 . 1 1 7}$ & $\mathbf{1 0 . 4 7 1 . 0 0 7}$ & $\mathbf{1 3 . 2 3 1 . 8 4 5}$ \\
\hline
\end{tabular}

Sumber : Data Olahan

Rumus:

Net Profit Margin $=\frac{\text { Laba Bersi5 sesuda } 5 \text { pajak }}{\text { Pendapatan operasional }} \times 100 \%$

$N P M=\frac{\text { A.FGH.CAT }}{\text { G.FIT.AHC }} \times 100 \%=30,25 \%$

Artinya: Pada tahun 2015 NPM BPR Paro Laba sebesar 30,25\% yang membuktikan kalau tiap Rp. 1,00 pendapatan operasional tidak mampu menciptakan keuntungan bersih Rp. 0,3025. Dapat membuktikan Semakin tinggi nilai NPM, semakin besar laba bersih yang diperoleh bank pada tingkat penjualan tertentu, hal ini menunjukkan bahwa NPM berada di posisi tidak sehat. Pada tahun 2016 NPM BPR Paro Laba sebesar 33,93\% yang membuktikan bahwa NPM berada di posisi tidak sehat karena berada dibawah standar yang ditentukan, pada tahun 2017 NPM sebesar 30,25\%, hal ini menunjukkan bahwa NPM berada di posisi tidak sehat, pada tahun 2018 NPM sebesar 31,50\% NPM juga berada di posisi tidak sehat dan tahun 2019 NPM sebesar 30,01\% NPM Juga berada di posisi tidak sehat.

2. Return On Assets (ROA)

ROA Menunjukkan kemampuan suatu perusahaan menghasilkan laba dari aktiva yang JAIM: Jurnal Akuntansi Manado | 401 
JAIM: Jurnal Akuntansi Manado, Vol. 2 No. 3 Desember 2021

e-ISSN 2774-6976 dipergunakan(Putri, 2017). Berdasarkan data yang diperoleh ROA BPR Paro Laba ditunjukkan pada tabel di bawah ini. Penetapan peringkat ROA Menurut standar BI No. 6/23/DNDP Tahun 2004 adalah sangat sehat $\mathrm{ROA}>1,5 \%$, sehat $1,25 \%<\mathrm{ROA}<=1,5 \%$, Cukup Sehat $0,5 \%<R O A<=1,25 \%$, Kurang Sehat $0<R O E<=5 \%$, Tidak Sehat ROE $<=0 \%$

Tabel 6

Perhitungan Return On total Assets (ROA) BPR Paro Laba

Tahun 2015 - 2019

(Ribuan Rp)

\begin{tabular}{lrrrrr}
\hline \multicolumn{1}{c}{ Komponen } & \multicolumn{1}{c}{ 2015 } & \multicolumn{1}{c}{2016} & \multicolumn{1}{c}{2017} & \multicolumn{1}{c}{2018} & \multicolumn{1}{c}{2019} \\
\hline Laba sebelum pajak & 2.657 .306 & 3.477 .000 & 3.256 .419 & 4.114 .055 & 5.004 .959 \\
Total Aktiva & 18.839 .056 & 21.231 .567 & 22.582 .273 & 25.363 .380 & 28.041 .343 \\
\hline
\end{tabular}

Sumber : Data Olahan

Rumus :

Return on Assets $=\frac{\text { Laba Bersi } 5 \text { sebelum pajak }}{\text { Total Aktiva }} \times 100 \%$

$R O A=\frac{2.657 .306}{18.839 .056} x 100 \%=14,10 \%$

Artinya : Kemampuan BPR Paro Laba dalam menghasilkan laba terhadap penggunaan sejumlah aktiva perusahaan dengan nilai ROA sebesar $14,10 \%$ dengan maksud kalau tiap Rp. 100 aktiva yang dipunyainya, bank mampu menghasilkan laba bersih sebelum pajak sebesar Rp. 0,1410. Menurut standar BI bank yang sangat sehat adalah bank yang memiliki ROA lebih dari 1,5\%, sementara BPR Paro Laba Tahun 2015 mampu menghasilkan ROA sebesar $14,10 \%$ melebihi dari standar yang telah ditentukan. Tahun 2016 Kemampuan BPR Paro Laba dalam menghasilkan ROA sebesar $16,37 \%$ hal ini menunjukkan bank berada diposisi sangat sehat, pada tahun 2017 Kemampuan BPR Paro Laba dalam menghasilkan ROA sebesar 14,46\% hal ini menunjukkan bank berada di posisi sangat sehat, tahun 2018 Kemampuan BPR Paro Laba dalam menghasilkan ROA sebesar $16,33 \%$ ini menunjukkan bank berada diposisi sangat sehat, Kemampuan BPR Paro Laba tahun 2019 dalam menghasilkan laba terhadap penggunaan sejumlah aktiva perusahaan dengan nilai ROA sebesar $17,84 \%$ dengan maksud kalau tiap Rp. 100 aktiva yang dipunyainya, bank sanggup menciptakan keuntungan bersih sebelum pajak sebesar Rp. 0,1784. Hal ini menunjukkan bank berada di posisi sangat sehat.

3. Return On Assets (ROE)

ROE merupakan rasio yang digunakan untuk mengukur kemampuan manajemen bank dalam mengelolah capital yang ada untuk mendapatkan net income(Tanor, M. O., 2015). Rasio 
JAIM: Jurnal Akuntansi Manado, Vol. 2 No. 3 Desember 2021

e-ISSN 2774-6976

Return On Equity (ROE) ialah perbandingan buat mengukur keahlian manajemen bank dalam menghasilkan keuntungan bersih dibanding dengan modal yang dipunyainya. Kriteria penetapan peringkat ROE Menurut standar BI No. 6/23/DNDP Tahun 2004 yaitu sangat sehat : ROE $>15 \%$, sehat: $12,5 \%<\mathrm{ROE}<=12,5 \%$, cukup sehat : $5 \%<\mathrm{ROE}<=12,5 \%$, kurang sehat : $0<\mathrm{ROE}<=5 \%$, tidak sehat : $\mathrm{ROE}<=0 \%$

\begin{tabular}{|c|c|c|c|c|c|}
\hline \multicolumn{6}{|c|}{$\begin{array}{c}\text { Tabel } 7 \\
\text { Perhitungan Return On Equity (ROE) BPR Paro Laba } \\
\text { Tahun 2015-2019 } \\
\text { (Ribuan Rp) }\end{array}$} \\
\hline Komponen & 2015 & 2016 & 2017 & 2018 & 2019 \\
\hline Laba Bersih & 2.174 .326 & 2.826 .031 & 2.612 .755 & 3.298 .398 & 3.970 .910 \\
\hline Modal Sendiri & 2.000 .000 & 6.000 .000 & 6.000 .000 & 6.000 .000 & 6.000 .000 \\
\hline
\end{tabular}

Sumber : Data Olahan

Rumus :

Return on Equity $=\frac{\text { Laba Bersi } 5 \text { sesuda } 5 \text { pajak }}{\text { Modal sendiri }} \times 100 \%$

Return on Equity $=\frac{2.174 .326}{2.000 .000} x 100=1,08 \%$

Artinya : kemampuan BPR Paro Laba dalam memperoleh keuntungan dari

modal sendiri pada tahun 2015 ROE BPR Paro Laba sebesar 1,08\% ini berarti tiap Rp.

1.- modal sendiri mampu menghasillkan Rp. 1,08 laba bersih setelah pajak. Menurut standar BI ROE yang baik adalah lebih dari $12 \%$, sementara BPR Paro Laba hanya mampu menghasilkan ROE sebesar $1,08 \%$ di bawah standar yang telah ditentukan. Pada tahun 2016 ROE BPR Paro Laba sebesar 47,10\% ini berarti ROE dapat dikatakan sangat sehat karena diatas standar yang telah ditentukan, Pada tahun 2017 ROE BPR Paro Laba sebesar 43,54\% ini berarti ROE dapat dikatakan sangat sehat, tahun 2018 ROE BPR Paro Laba sebesar 54,97\% ini berarti ROE dapat dikatakan juga sangat sehat, Pada tahun 2019 ROE BPR Paro Laba sebesar 66,18\% ini berarti dapatdikatakan sangat sehat.

Berdasarkan hasil analisis di atas dilihat dari rasio likuiditas, perkembangan cash ratio, quick ratio, dan loan to deposit ratio pada Bank Perkreditan Rakyat (BPR) Paro Laba Tondano dalam lima tahun terakhir menunjukkan kecenderungan berfluktuatif. Dari uraian di atas dapat dilihat, untuk cash ratio pada Bank Perkreditan Rakyat (BPR) Paro Laba Tondano, bank mampu memenuhi utang jangka pendek menggunakan alat likuid yang dimiliki oleh bank. Perkembangan quick ratio dapat dilihat dari tahun 2015,2016, dan 2018 bank berada diposisi cukup sehat. Kemudian pada tahun 2017, 2019 menunjukkan kalau kemampuan bank BPR Paro Laba dalam memenuhi kewajibannya kepada para deposan dengan harta yang paling likuid masih kurang baik. Ini berarti semakin tinggi jumlah quick ratio BPR Paro Laba Tondano semakin likuid kemampuan bank dalam memenuhi kewajibannya pada deposan. Kemudian untuk Loan To Deposit Ratio dari uraian diatas dapat dilihat tahun 2015 sampai 2019 menunjukkan bahwa bank berada di posisi cukup sehat karena berada $85 \%<$ LDR $<=100 \%$ yang ditetapkan oleh $\mathrm{BI}$ dapat dikatakan bank belum mampu melunasi kembali kewajibannya kepada nasabah yang sudah memberikan dananya kepada bank. Maksudnya semakin kecil jumlah Loan To Deposit Ratio BPR Paro Laba maka semakin besar tingkatan likuiditas bank BPR Paro Laba tersebut.

Berdasarkan hasil analisis di atas dilihat dari Rasio Profitabilitas, perkembangan Net Profit Margin, Return On Assets (ROA), Bank Perkreditan Rakyat (BPR) Paro Laba Tondano dalam lima tahun terakhir menunjukkan kecenderungan berfluktuatif. Dari uraian di atas dapat dilihat bahwa Net Profit Margin BPR Paro Laba tidak mampu dalam menghasilkan Laba bersih dari jumlah kegiatan operasinya. Menurut standar BI Net Profit Margin BPR Paro Laba berada posisi tidak sehat karena NPM Kurang dari 51\%. Untuk Return On Assets (ROA) menunjukkan bahwa tahun 2015-2019 BPR Paro Laba berada di posisi sangat sehat sesuai dengan standar BI bank 
JAIM: Jurnal Akuntansi Manado, Vol. 2 No. 3 Desember 2021

e-ISSN 2774-6976

berada diposisi sangat sehat jika lebih dari 1,5\%. Sedangkan Return On Equity (ROE) Bank Perkreditan Rakyat (BPR) Paro Laba Tondano dalam lima tahun terakhir menunjukkan kecenderungan mengalami kenaikan. Dari uraian di atas dapat dilihat bahwa BPR Paro Laba mampu memperoleh laba dari modal sendiri. Menurut standar BI ROE Bank BPR Paro Laba pada tahun 2016-2019 ROE mampu memenuhi standar sesuai dengan yang telah di tetapkan yaitu lebih dari $12 \%$.

\section{KESIMPULAN DAN SARAN}

Dapat disimpulkan untuk rasio Likuiditas dan profitabilitas PT. BPR Paro Laba Tondano selama periode Tahun 2015-2019 Cash Ratio (CR) dalam keadaan sehat ini berarti bank mampu memenuhi hutang jangka pendek menggunakan perlengkapan likuid yang dipunyai oleh bank. Quick Ratio dari tahun 2015-2018 dalam keadaan cukup sehat dan kurang sehat karena berada di bawah standar yang telah ditentukan oleh $\mathrm{BI}<=10 \%$ ini berarti bank belum mampu memenuhi kewajiban kepada para deposan dengan harta yang sangat likuid. Untuk Loan to Deposit Ratio pada tahun 2015-2019 berada di posisi cukup sehat karena berada dibawah standar $<=75 \%$ berarti bank tidak mampu melunasi kembali kewajiban kepada nasabah menggunakan kredit yang diberikan bank dengan dana yang diterima bank. Sedangkan untuk Net Profit Margin di posisi tidak sehat karena berada dibawah standar BI yaitu $<51 \%$ ini berarti bank belum mampu dalam menghasilkan laba bersih dari kegiatan operasinya, untuk Return On Assets sudah dapat dikatakan baik karena berada di atas standar yang telah ditentukan oleh $\mathrm{Bl}$, yaitu sebesar $1,5 \%$ ini berarti bank mampu menghasillkan laba bersih sebelum pajak dari jumlah aktiva yang dimiliki. Dan untuk Return On Equity pada tahun 20162019 sudah baik karena berada di atas standar BI sebesar 12\% ini berarti bank sanggup dalam menghasilkan keuntungan dari modal sendiri, tetapi pada tahun 2015 Return On Equity berada di bawah standar yang telah ditentukan.

Bagi Pt. Bank Perkreditan Rakyat Paro Laba untuk lebih meningkatkan rasio likuiditas perusahaan menjadi lebih baik dengan meningkatkan kemampuan bank dalam memenuhi kewajiban kepada para nasabah dan untuk rasio profitabilitas yaitu Net profit margin untuk lebih ditingkatkan agar bank mampu dalam menghasilkan laba dari kegiatan operasinya sedangkan untuk Return On Assets dan Return on Equity yang sudah baik untuk dipertahankan dan ditingkatkan demi kemajuan bank saat ini dan di masa yang akan datang.

\section{DAFTAR PUSTAKA}

Abolladaka, J. (2015). Analisis Laporan Keuangan Untuk Menentukan Tingkat Kesehatan Keuangan Bank Pada Pt. Bank Perkreditan Rakyat Christa Jaya Perdana Di Kota KupangTahun 2012-2014. 10, 748-754.

Anggraeni, R. K., \& D. (2014). Analisis Pengelolaan Kredit Untuk Meningkatkan Likuiditas dan Profitabilitas PT BPR Wlingi Pahala Pakto. Jurnal Administrasi Bisnis, 12(2), 1-10.

Badria, Medianana dan Marlius, D. (2018). Analisis Rasio Likuiditas Pada PT. Bank Perkreditan Rakyat Lengayang. Akademi Keuangan Dan Perbankan Padang, 1-11.

Faizal Cholid. (2014). Pengaruh Rasio Likuiditas, Rasio Profitabilitas, Rasio Aktivitas, Rasio Solvabilitas, Dan Rasio Nilai Pasar Terhadap Return Saham. Fakultas Ekonomi Universitas Negeri Yogyakarta.

Fitri, H. Y., \& Marlius, D. (2019). Analisis Rasio Likuiditas Pada Pt . Bank Nagari Kasang. Akademi Keuangan Dan Perbankan Padang, 1-9.

Handayani, M., \& Marlius, D. (n.d.). Analisis Tingkat Kesehatan PT. BPR Batang Kapas. Herdyanto, R. (2012). Analisis Rasio Keuangan Untuk Mengukur Kinerja Keuangan Bank Pada

PT BPR Puri Dharma Ponorogo. Naskah Publikasi Universitas Muhammadiyah Surakarta.

Kasmir. (2014). Analisis Laporan Keuangan (ke-1). PT raja Grafindo persada.

Munawir. (2014). Analisis Laporan Keuangan (ke-4). yogjakarta: liberty.

Nur, D Eva dan Elim, I. (2015). Analisis Laporan Keuangan Dalam Mendukung Keputusan Pemberian Kredit Pada Pt. Bank Perkreditan Rakyat Nusa Utara. Jurnal Emba, 3(2), 326335. 


\section{JIIII}

JAIM: Jurnal Akuntansi Manado, Vol. 2 No. 3 Desember 2021

e-ISSN 2774-6976

Ottay, M. C., \& Alexander, S. W. (2015). Analisis Laporan Keuangan Untuk Menilai Kinerja Keuangan Pada Pt. Bpr Citra Dumoga Manado. Jurnal Emba, 3(1), 923-932.

Palar, D. S., \& D. (n.d.). Analisis Tingkat Kesehatan PT. Bank SULUT, Tbk Dengan Menggunakan Rasio Keuangan. 10,1-10.

Pangemanan, W. I, dan D. (2017). Analisis Rasio Likuiditas, Leverage Dan Rrofitabilitas Untuk Menilail Kinerja Keuangan Pada PT. Bank Central Asia, TBK. Cabang manado. Jurnal Riset Akuntansi Going Concern, 12(2), 25-34.

Putri, Y. dan A. (2017). Analisis Laporan Keuangan Berdasarkan Tingkat Profitabilitas Pada PT. Bank Perkreditan Rakyat LPN Tarantang Kabupaten Dharmasraya. Akademi Keuangan Dan Perbankan Padang, 1-12.

Rabuisa, W. F. D. (2018). Analisis Laporan Keuangan Dalam Menilai Kinerja Keuangan Perusahaan Pada Bank Perkreditan Rakyat (BPR) Dana Raya Manado. Jurnal Riset Akuntansi Going Concern, 13(2), 325-333.

Rahmayeli, D. S., \& Marlius, D. (2017). Analisis Kinerja Keuangan Pada PT. Bank Perkreditan Rakyat (BPR) Batang Kapas Pesisir Selatan. No Title.

Tanor, M. O., \& D. (2015). Analisis Laporan Keuangan Dalam Mengukur Kinerja Keuangan Pada PT. Bank Artha Graha Internasional Tbk. Emba, 3(3), 639-649.

Zebua Yuniman. (2014). Analisis Likuiditas Bank Mandiri Tahun 2009-2013. Jurnal Ecobisma, 1(2), 19-25. 